\title{
The Role of The Voice Of Indonesia As A Public Diplomic Media Through The Diplomatic Forum Event Program
}

Fornia $^{1}$, and Arif Susanto ${ }^{2}$

${ }^{1,2}$ Institut Komunikasi dan Bisnis LSPR, Jakarta, Indonesia

\begin{abstract}
Voice of Indonesia is part of institution broadcast public that owned by Radio of Republic Indonesia. Diplomatic Forum is one of Voice of Indonesia's program. The concept of this program is talk show who talking about politic, economic and culture issues. The participant of this program are the ambbassador, part of the ministry or academics who expert in discussion topic. This research is to describe, analysis role of Voice of Indonesia through Diplomatic Forum Programme. This research is use by qualitative methods with constructivist paradigm. The result of this research taken by semistructure interview and use literature study. The result of this research found that Diplomatic Forum Programme is one of Voice of Indonesia's implementation from vision and mission Voice of Indonesia to become one of Instution owned by nation that can to build character nation and make positive image into foreign. Through diplomatic forum, foreigner listeners more understand about policies that apply in Indonesia thru the result of expert's discussion in that programme and also help promote Indonesia into foreigners.
\end{abstract}

Keywords: media; diplomacy; public diplomacy; Voice of Indonesia; radio

\section{Peran Voice Of Indonesia Sebagai Media Diplomasi Publik Melalui Program Acara Diplomatic Forum}

\begin{abstract}
ABSTRAK
Voice of Indonesia merupakan salah satu bagian program dari Lembaga Penyiaran Publik yang dimiliki oleh Radio Republik Indonesia. Diplomatic Forum adalah salah satu program acara yang dikemas dengan acara talkshow dimiliki oleh Voice of Indonesia. Program acara ini membahas mengenai isu-isu politik, ekonomi dan budaya dengan narasumber duta besar negara sahabat untuk Indonesia dan atau pejabat dari kementerian terkait serta pengamat. Penelitian ini dilakukan untuk mendeskripsikan, menganalisa peran Voice of Indonesia melalui program acara Diplomatic Forum dalam melakukan diplomasi publik. Penelitian ini menggunakan metode kualitatif dengan paradigma konstruktivis. Hasil dari penelitian ini diambil dengan cara mewawancara semistruktur dan memakai studi literatur. Hasil dari penelitian menemukan bahwa program acara Diplomatik Forum adalah salah satu bentuk nyata dari pelaksana Visi dan Misi Voice of Indonesia untuk menjadi salah satu penyiaran dimiliki Indonesia yang membangun karakter bangsa di luar negeri dan juga membuat citra positif Indonesia di luar negeri. Melalui program ini masyarakat luar negeri lebih lagi memahami kebijakan-kebijakan yang berlaku di Indonesia melalui hasil diskusi oleh narasumber Diplomatic Forum dan mempromosikan Indonesia ke kancah Internasional.
\end{abstract}

Kata kunci: media; diplomasi; public diplomacy; Voice of Indonesia; radio 


\section{INTRODUCTION}

Each country must be able to establish good relations with other countries in order to create a peace between countries. Efforts to establish good relations can be carried out through mutually beneficial cooperation and diplomatic steps. Success in establishing cooperation and expertise in diplomacy as well as being able to build a good image in international relations. In establishing relations between countries today, diplomacy is needed that involves all components of society, including journalists and the media (Muhammad, 2017).

Media is one of the facilities or infrastructure that makes it easier for people to get access to communication and information. Media that can be in the form of information media in the form of news distributed through print, electronic, or network. The media has a great influence in social life so that it can affect diplomatic relations between countries which should be the authority of the government of a country. Now, the media has become a necessity for humans along with the strengthening of the role of the media in people's lives (Sanjaya, 2011).

The media has a significant influence in social life. The media describes the opportunities and challenges to reap responses and feedback from the public. In addition, the media becomes a communication partner so that there is a communication process of interaction and glue between community members. The media also changed the paradigm of diplomacy from government to government to people to people (Sanjaya, 2011).

One of the media owned by Indonesia in carrying out non-state diplomacy is through Radio Republik Indonesia or often referred to as RRI. The task of carrying out the function of providing information abroad and participating in carrying out non-state diplomacy (second track diplomacy) is carried out by a special RRI station, namely the RRI Foreign Broadcasting Station or also called Voice of Indonesia (VOI). Many programs broadcast by VOI contain information about Indonesia intended for the international community (voinews.id).

Starting July 1, 2008, Voice of Indonesia broadcasts 24 hours a day in 10 languages including Indonesian, German, English, Spanish, French, Arabic, Japanese, Mandarin, Malay, and Korean via 9,525 kHz terrestrial transmission and the internet. However, after reorienting its broadcast program, since 2010, Voice of Indonesia only has 8 language programs: Indonesian, English, Arabic, Mandarin, Japanese, French, Spanish, and German. But in 2017, Voice of Indonesia reintroduced, the Dutch language program. So, currently Voice of Indonesia has 9 language services (voinews.id). Listeners can listen to all programs on Voice of Indonesia, through: terrestrial in SW, streaming through the website www.voinews.id and can also use smartphones through an application called RRI Play (voinews.id).

Starting in 2011, Voice of Indonesia broadcasts a new program, namely the Diplomatic Forum to realize the mission of second track diplomacy. Diplomatic Forum is one of the program programs that are packaged with talk shows owned by Voice of Indonesia. This program discusses political, economic and cultural issues with ambassadors of friendly countries to Indonesia and/or officials from relevant ministries and observers. 
This program was created at the initiative of the Head of Overseas Broadcasting Station, Voice of Indonesia, Mr. Kabul Budiono in 2011 who now serves as one of the Supervisory Boards of the TVRI Public Broadcasting Institution. This program presents a talk show or talk show with various themes from youth issues, peacekeeping, APEC, MEA, Deradicalization, and others.

The Diplomatic Forum event was held in collaboration with Voice of Indonesia and Pro 1 Radio Republik Indonesia Jakarta. The purpose of this program is to carry out its function as a second track diplomacy. Based on the background of the problems described above, the researcher examines the role of Voice of Indonesia in running public diplomacy media through the Diplomatic Forum program which is held three times a year. Listeners who listen to this program can also be listened to by the public both at home and abroad. The theme presented by Voice of Indonesia is also related to current international issues and is discussed with competent people in their fields.

Below are some points regarding the formulation of the problem, research objectives and research benefits. Formulation of the problem: What is the role of Voice of Indonesia as a medium of public diplomacy through the Diplomatic Forum program? Research purposes: To describe the program of the Diplomatic Forum dan To describe and analyze the role of Voice of Indonesia through the Diplomatic Forum program in conducting public diplomacy.

\section{Agenda Setting Theory}

Quoted in a book entitled Agenda Setting Mass Media it is written that Bernard Cohen (1963) wrote the definition of Agenda setting is: "Perhaps they are not very successful in telling what someone thinks, but they are usually successful in telling people what they should think." (Baran \& Davis, 2010). It begins with this that the world looks different to different people, depending not only on their personal interests, but also on the maps given to them by the writers, editors, and publishers of the newspapers they read. In this case it is difficult to ignore the venom of the limited effect of mass media on public opinion. This writing from Cohen has become the basis of the so-called agenda setting theory of mass media (Tamburaka, 2012).

Agenda setting theory or in English we mention Agenda Setting Theory is a theory which states that the mass media is the center of truth determination with the ability of the mass media to transfer two elements, namely awareness and information into the public agenda by directing public awareness and attention to issues. considered important by the mass media. The two basic assumptions that most underlie research on agenda setting are: (Tamburaka, 2012) (1) The press and mass media do not reflect reality; they filter and shape issues; and (2) The concentration of mass media is only on a few problems of society to be presented as issues that are more important than other issues.

Priming shows the influence of the media in setting the agenda. According to Severin and Tankard Jr., the definition of priming is quoted in the book Agenda Setting of mass media. 
Priming is the process by which the media focuses on some issues and not on others and thereby changes the standard by which people evaluate electoral candidates (Severin and Tankard, Jr., 2010).

Priming in agenda setting is seen from a situational and contextual perspective. Situational means that agenda setting theory can apply in certain situations that require a large amount of public attention, while contextually applies only to certain issues or problem contexts. Priming is an important part of the agenda setting which contains a statement that the media draws attention to certain political aspects from other aspects (Tamburaka, 2012). Manheim argues that this agenda setting predicts the media agenda to influence the public agenda, while the public agenda itself ultimately influences the policy agenda (Severin and Tankard Jr., 1992).

1. The media agenda consists of the following dimensions.

a. Visibility (visibility), namely the amount and level of prominence of the news.

b. Audience salience (level of prominence to the audience), namely the relevance of news content to the needs of the audience.

c. Valence (valence), which is a pleasant or unpleasant way of reporting an event.

2. The audience agenda, consisting of the following dimensions.

a. Familiarity (familiarity), namely the degree of awareness of the audience on a particular topic.

b. Personal salience (personal prominence), namely the relevance of individual interests with personal characteristics.

c. Favorability (pleasure), namely the consideration of being happy or not happy with the news topic.

3. The policy agenda consists of the following dimensions.

a. Support (support), namely fun activities for the position of a particular news.

b. Likelihood of action (possibility of activity), namely the possibility of the government to carry out what is likened to.

c. Freedom of action (freedom of action), namely the value of activities that may be carried out by the government (Nurudin, 2007).

Reese (1991) suggests that the content of media messages or media agendas is the result of pressure from within and outside the media organization. In other words, media content is a combination of internal programs, managerial and editorial decisions and external influences originating from non-media sources, such as socially influential individuals, government officials, advertising and so on (Morissan, Wardhani, Hamid, 2013).

The power of the media in shaping the public agenda depends in part on the relationship of the media concerned with the center of power. If the media has a close relationship with the elite groups of society, then these groups will influence the media agenda and in turn will also influence the public agenda. In this case, there are four types of power relations between the mass media and sources of power outside the media, especially the government/rulers (Morissan, Wardhani, Hamid, 2013). 
Littlejohn and Foss (2005) suggest that there are four types of power relations between the mass media and the authorities, and between the mass media and the authorities. The four types of relationships are as follows:

a. High-power sources, high-power media

The first type is the so-called high-power source, high power media or 'big outside power source, big media power' relationship. For example, there is a close relationship between public officials and the managers or owners of the mass media. If the two work together, there will be a mutually beneficial relationship between the two parties and it will affect the public agenda that is created, vice versa.

b. High-power sources, low-power media

The second type is high-power source and low-power media, namely large external power sources with small media power, here outside sources of power are likely to coordinate with the media, namely using the media to achieve their goals. For example: when politicians or political parties buy broadcast media time by placing political advertisements or sponsoring a program or a president gives certain media the opportunity to conduct interviews.

\section{c. Lower-power sources, high-power media}

The third type is the relationship between small external power sources and large media power. In this case, the media concerned themselves determine what the agenda is. The media can ignore or report or reduce the intensity of reporting on certain events that may be important to the community.

\section{d. Low-power sources, low-power media}

The fourth type is the relationship which is a low-power source and low-power medium between a small external power source and a small medium. In this type of relationship, the public agenda will be determined by the event itself and not determined by the media or political leaders (Morissan, Wardhani, Hamid, 2013).

\section{Public Diplomacy}

Edward R Murrow is a diplomat and journalist who headed the USIA (United States Information Agency) in 1961, which has provided a deep inspiration for Edmund Gullion to develop the study of public diplomacy by establishing the Edward Murrow Center of Public Diplomacy at Tifts University founded in 1965. Conceptually, Gullion through this institution defines public diplomacy as, "Public Diplomacy.. deals with influence of public attitudes on the formation and execution of foreign policies. It includes dimensions of international relations beyond traditional diplomacy; the cultivation by governments of public opinion in other countries; the interaction of private groups and interests in one country with those of another; the reporting of foreign affairs and its impact on policy; communication between those whose job is communication, as between diplomats and foreign correspondents; and the processes of inter-cultural communications" (Rahmawati, 2016). The purpose of public diplomacy is to fulfill the national interests of each country. Convey information, spread culture 
and build a positive image through nation branding (Rahmawati, 216).

The main actor in diplomacy is the main characteristic of traditional diplomacy, where the main actor of diplomacy is the country represented by its representative in the destination country. Although the effects of globalization have presented new actors in relations between countries, the state is still the main player and coordinator in the implementation of public diplomacy (Rahmawati, 2016). Non-state actors in diplomacy have become an inseparable part in situations where every individual and group is connected to one another. Non-state actors, referring to Hill's opinion, are individuals or groups, even though they use the facilities provided by the state, they do not need the government to carry out international relations (Rahmawati, 2016).

Research on public diplomacy can be seen in three areas, first the debate on public diplomacy arises on the issue of the objectives of public diplomacy itself. Second, public diplomacy is discussed or debated in terms of the manner in which public diplomacy is carried out. Third, public diplomacy is debated in terms of public diplomacy actors (Rachmawati, 2016). The table below is a simple chart for mapping out public diplomacy.

Tabel 1 Mapping of Public Diplomacy

\begin{tabular}{|c|c|c|c|}
\hline \multirow[t]{2}{*}{ Issue } & \multicolumn{3}{|c|}{ Approach } \\
\hline & Rationalist & Reflectivist & Constructivist \\
\hline Objective & $\begin{array}{l}\text { Security and } \\
\text { Economic } \\
\text { Cooperation }\end{array}$ & $\begin{array}{lr}\text { Awareness } & \text { of } \\
\text { values/norms and } \\
\text { culture }\end{array}$ & $\begin{array}{l}\text { Influencing government and } \\
\text { public perceptions outside the } \\
\text { country }\end{array}$ \\
\hline Methods & $\begin{array}{lr}\text { Monologue } & - \\
\text { Dialogue between } \\
\text { countries }\end{array}$ & $\begin{array}{l}\text { Government } \\
\text { dialogue, } \\
\text { interaction } \\
\text { between citizens }\end{array}$ & $\begin{array}{l}\text { Government dialogue and } \\
\text { interactions between citizens }\end{array}$ \\
\hline Actor & 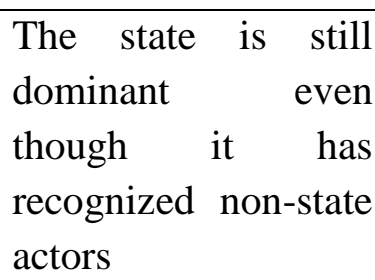 & & $\begin{array}{l}\text { State and non-state actors are in the } \\
\text { same position as subjects who } \\
\text { interpret international norms }\end{array}$ \\
\hline
\end{tabular}

Source: Researchers Notes

\section{METHODS}

This research uses qualitative methods with data collection techniques using semi-structured interviews, literature studies through books, online media and documents from Voice of Indonesia. The paradigm used in this study is the constructivist paradigm. Six people were interviewed as resource persons. The sources in this study include producers, initiators, moderators, resource persons and listeners from the Diplomatic Forum program. 


\section{RESULT AND DISCUSSION}

\section{Diplomatic Forum Program Objectives}

The purpose of public diplomacy for constructivists does not lie in the national interest alone because he believes that national interests will be able to change in line with changes in state identity that occur due to interactions between countries. Public diplomacy is then better understood as the result of the interaction of actors in conveying certain messages to other actors and or forming certain meanings in their minds. Public diplomacy is also understood as an attempt to influence international norms through public discourse (Rachmawati, 2016)

From the explanation above, the purpose of the constructivist approach is not only for the national interest because the identity of a country will change due to interactions between countries and form certain meanings in the minds of the people from the interaction of actors. Talking about the image of Indonesia, quoted from Detik.com. In 2016 Joko Widodo wanted Indonesia to have a clear, positive and known image to the world. In addition, he also wants Indonesia to increase its competitiveness compared to other countries (Iqbal, 2016).

This he made at the opening of a limited meeting themed 'Strategies for Improving Indonesia's Image in the World' at the Presidential Office, Palace Complex, Jakarta (27 September 2016). He made this statement because the development of nation branding provided by independent ministries, such as: the Ministry of Trade and the Ministry of Tourism to the world is very different. The Ministry of Trade has the tagline 'Remarkable Indonesia' while the Ministry of Tourism carries the tagline 'Wonderful Indonesia' (Iqbal, 2016).

From there, Joko Widodo saw the existence of egocentrism in building nation branding. For this reason, Joko Widodo asked that everything be discussed and corrected together because if left unchecked, it will result in a positive image of Indonesia in the eyes of the international community which tends to be fragmented and run on its own (Iqbal, 2016). This is where the role of Voice of Indonesia helps in strengthening a positive image through the Diplomatic Forum program. The objectives of the establishment of the Diplomatic Forum program according to the producers and initiators of this program are as follows: The purpose of this program according to Mrs. Ani Hasanah Mubarok as the producer of the program is to straighten out what is being reported regarding bad news about Indonesia in foreign media, to provide true information to the outside world about Indonesia and that has also become the task of Voice of Indonesia as media that brought Indonesia.

Quoted from the online news Republika.co.id, Indonesia cannot be separated from the spotlight of the Indonesian media. Based on a company in the field of media intelligence, data analysis and strategic studies called the Indonesia Indicator (I2) research. The research uses AI (Artificial Intelligence) software. It was recorded that from January 1 to July 15 2017, there were 468 international online media reporting 33,887 news about Indonesia. This data was obtained from all English-language online media reports from 139 news stories (Fakhruddin, 2017). 
In a press release on July 27, 2017 which was sent to Republik.co.id online news, Rustika Herlambang as Director of Communications for Indonesia Indicator stated that there were three issues that emerged dominantly in the international media, such as; economic and trade issues, the tourism industry, ISIS and terrorism. These three big issues account for $64 \%$ of all news about Indonesia. On average, 4,841 Indonesian news reports were present in foreign media and February 2017 was the month with the highest exposure of Indonesian news in foreign media (Fakhruddin, 2017).

One example of negative issues reported by foreign media. As quoted from a statement from one of the media from the UK, namely Independent.co.uk: "The most dangerous cities were all located in South and South East Asia, the Middle East or Africa, with Karachi in Pakistan deemed the most dangerous using the index's criteria. It was followed by Yangon in Myanmar, Dhaka in Bangladesh, Jakarta in Indonesia and Ho Chi Minh City in Vietnam" (Coffey, Oktober 16, 2017).

The quote above shows that Independent.co.uk states that Jakarta is one of the cities included in the list of dangerous cities. This is one of the evidences of foreign media reporting negatively about Indonesia. Therefore, Voice of Indonesia as one of the media owned by the government straightens bad issues and provides more information about Indonesia through the programs that are presented. In addition to diplomatic forums, many programs are offered by Voice of Indonesia to provide correct information about Indonesia as well as to provide an overview of Indonesia to foreign listeners. Pesona Indonesia is one of the programs owned by Voice of Indonesia. This program discusses information about Indonesian art, culture and tourism, the Indonesian charm program is made for listeners to get to know Indonesia more deeply about Indonesia's wealth, culture and tourism (Voice of Indonesia Documentation). The researcher also asked the same question to Kabul Budiono as the initiator in making this program. He explained that the purpose of this program was to introduce Voice of Indonesia to other agencies so that Voice of Indonesia gets attention. In addition, this program is to inform about Indonesia, connect Indonesia with other countries and there are also efforts for the public relations side to image Indonesia through Voice of Indonesia, publicity and promotion of Voice of Indonesia.

The researcher also asked the purpose of public diplomacy carried out by Indonesia to the Expert Resource, namely Beginda Pakpahan as one of the lecturers of International Relations, University of Indonesia. He also stated that Indonesia's public diplomacy is carried out through many agents, not only from the government side but also from the non-government side which aims to give a positive image of the Indonesian state to the world. According to him, RRI is also trying to see and analyze the developing situation through the Diplomatic Forum program.

According to Jameel, Voice of Indonesia listeners, the program provided by Voice of Indonesia is independent and does not mention problems that occur in other countries, that's how VOI can gain the trust of listeners. In addition, this program at VOI is very informative about Indonesian culture, Indonesian history, music, and much more. According to Jameel, Voice of Indonesia in making a topic in the program was well prepared, informative and professional. That is Jameel's assessment of Voice of Indonesia because he listens to Voice of Indonesia every day. He said that after he heard the program presented by Voice of Indonesia, he could 
describe Indonesia well through the content presented. According to him, the content offered by Voice of Indonesia is informative and entertaining. From the two statements of listeners from Pakistan, both of them gave positive comments about the program presented by Voice of Indonesia. This shows that the goals expressed by Ani Hasanah Mubarok and Kabul Budiono provide results in accordance with their goals.

Mark Leonard clarifies public diplomacy through 3 main pillars, namely news management, strategic communication and relationship building (Rachmawati, 2016). News management is the first dimension to managing communication on day to day issues, reflecting the increasing need to align communication with traditional diplomacy (Leonard, 2002). Information management carried out by Voice of Indonesia is through the official website of Voice of Indonesia at www.voinews.co.id. Besides being able to access news information about Indonesia, on the website listeners from all over the world can listen to all broadcasts of programs presented by Voice of Indonesia.

In determining a topic in a diplomatic forum program, of course, supporting data is needed in it. For example, recently a diplomatic forum was held in Palembang and raised the theme of the implementation of the Asian Games. This theme was chosen because it coincided with the Asian Games event. In the question and answer session, of course, questions are made according to the conditions that occurred during the event and how the facilities were built after the event took place. This is reinforced by a statement from the moderator of the diplomatic forum program when the researcher asked what topic the moderator had recently brought up.

The strategic communication built by Voice of Indonesia is through one of their program programs, namely the Diplomatic Forum through the selection of each theme in the program. The researcher asked the producers and initiators of the program, namely Mr. Kabul Budiono and Ani Hasanah. As stated by the producer of the Diplomatic Forum program, Ani Hasanah. He said that it was not easy to determine a theme in the Diplomatic Forum program, which required teamwork. The theme taken is issues related to Indonesian issues with international issues. Well, from there VOI can invite resource persons who are competent in their fields. Not only that, the researcher also asked the same thing about how to choose a theme in the diplomatic forum program to the initiator of the program, namely Kabul Budiono. Kabul Budiono emphasized that the selection of issues or themes in the Diplomatic Forum program was about cooperation between Indonesia and abroad in providing information about Indonesia abroad that was happening based on reality or on big days and had news value or what was called news value.

If we look at the two statements given by the producers and initiators of this program, they both answered that the theme of this program was about issues related to Indonesia and foreign countries. Then, the choice of the theme can also be matched with big dates so that the speakers at the Diplomatic Forum can be adjusted to the theme that has been chosen which of course also has news value. This is in accordance with the implementation of the Diplomatic Forum program. For example, recently, on August 25, 2018, the Diplomatic Forum program was held in Palembang with the theme "Energy of Asia: Working Together for the Success of the 2018 Asian Games". The event was attended by the Acting Mayor of Palembang, Dr. H. Akhmad 
Nadjib, President of Inasgoc Yudi Sutrasna, President of JSC Bambang Supriyanto, Head of the Provincial Tourism Office Irene Camilyn Sinaga, President of Sepak Takraw (Datoek Abdul) Halim bin Kader.

The diplomatic program of the forum yesterday was held in Palembang because Palembang is one of the venues for the Asian Games and the topic coincides with the momentum of the Asian Games which are currently taking place in two cities in Indonesia, namely Jakarta and Palembang. The realization of this event is also due to the collaboration between Voice of Indonesia and Radio Republik Indonesia Palembang. Not only that, this program also invited guest stars according to the theme, students from the English Language Education study program, Faculty of Teacher Training and Education (FKIP) Universitas PGRI Palembang were also present as participants in the program.

This statement is also supported by a statement by Beginda Pakpahan as a lecturer in International Relations, University of Indonesia. The researcher asked Beginda Pakpahan whether the theme of the program was one of Voice of Indonesia's efforts to carry out public diplomacy. Beginda replied that the choice of theme depends on the theme presented, from there it is analyzed and observed its development. Then, VOI invited relevant resource persons to answer the theme.

The researcher validated to ask about how the message he captured through the Diplomatic Forum to one of the Voice of Indonesia listeners named Azam Ali Somroo came from Pakistan. He replied that the diplomatic message of the forum is to convey the attention of the world's citizens on very important issues related to one's life. He also believes that Voice of Indonesia contributes to look at all issues and to find the best solution or solution. The researcher not only asked Azam Ali Somroo, the researcher also asked another listener, namely Jameel who came from Pakistan as well. The researcher asked Jameel about how the topics raised through the Diplomatic Forum program were.

The two responses from these listeners gave a positive picture for Voice of Indonesia in choosing a theme for the ears of its loyal listeners. Not only about the choice of topics, the researchers asked the loyal listeners of Voice of Indonesia, namely Azam and Jameel, but the researchers also asked them whether the speakers in the program were their main attraction in listening to the diplomatic forum. The message strategy carried out by Voice of Indonesia in conducting public diplomacy through diplomatic forums, the media used and the selection of moderators in this program. The researcher asked the producers of this program about what media was used for the diplomatic forum program. Ani Hasanah explained that the media used were websites, social media and RRI net. The researcher also asked Kabul Budiono about the use of any media in the forum's diplomatic program. Kabul Budiono explained that diplomatic forums use online media and rely on media convergence. The selection of event moderators is also important in implementing the program of this diplomatic forum. The researcher also asked the producers and the initiators of the diplomatic forum program about the selection of moderators in this program.

Kabul Budiono explained that to be a moderator in the diplomatic program of the forum, he could not only speak but also master the problem. He must also be able to liven up the 
atmosphere and dialogue so as to make the atmosphere more lively. After that, the researcher also asked the producer of this program, Ani Hasanah. According to him, to become a moderator in diplomatic forum programs, one can master good English and then master problems, broad knowledge, someone who is able to lead discussions and is confident. Therefore, the researcher asked one of the moderators of the diplomatic forum program, Daulat Pane, about what it takes to be a moderator in the diplomatic forum program, which is to be communicative, understand the situation and understand the sources so that the speakers feel comfortable when asked by the moderator. The researcher also continued the questions to the moderator. The researcher asked how the moderator brought the atmosphere and the reasons why he was interested in being a moderator of the forum's diplomatic program. The moderator brought the atmosphere of the event with a joking and friendly atmosphere so as to make the speakers present relaxed in answering the moderator's questions.

The moderator also thinks that being one of the moderators of the forum's diplomatic program is very challenging because to be a moderator of the forum's diplomatic program, one must have broad insight to master every topic and theme discussed. Relationship building is the next third dimension, this dimension is the most long-term development with individual keys through scholarships, student exchanges, training, seminars, conferences, building networks in the real and real world and giving people access to media channels. This differs from the diplomatic practice of maintaining contacts as the relationship develops between politicians and their associates, special counsel, business people and academics (Leonard, 2002). The relationship building carried out by Voice of Indonesia is through interactions through their official social media with listeners, voice of Indonesia emails, listener letters, inviting foreign listeners who are loyal to Voice of Indonesia to visit for a few days to Indonesia and make tourism visits.

For this reason, the researcher asked the producer of the Diplomatic Forum program, Ani Hasanah, about how to see the interest of foreign listeners regarding Indonesian information. He also replied that it was all obtained from the letters their listeners sent by post, email or through Voice of Indonesia's official social media. Not only that, the experience of foreign listeners came to Indonesia. It was also acknowledged by Mr. Beginda as a person who knew about the Diplomatic Forum because several times he had seen some outside listeners come there and conduct direct questions and answers with him. Here is Beginda Pakpahan's statement. The researcher also asked about the listeners who listened to the most diplomatic forums to the moderator of the event, namely Daulat Pane. According to Daulat Pane, the diplomatic listeners of the forum mostly come from South Asian countries such as Pakistan, Bangladesh, India. He also did not forget to thank listeners from abroad who have listened to the program broadcast through Voice of Indonesia. Ani Hasanah as the producer of the diplomatic forum also said that many Voice of Indonesia listeners came from South Asia.

Before the researcher conducted a question and answer session via whatsapp chat with Jameel, a loyal listener of Voice of Indonesia from Pakistan, the researcher and Jameel communicated by telephone via whatsapp. He was also asked about Voice of Indonesia. He immediately answered with great enthusiasm. He also immediately told about his experience of traveling with Ani Hasanah as one of the Voice of Indonesia staff who is also a producer on diplomatic 
forum programs and other Voice of Indonesia staff as well as Voice of Indonesia loyal listeners from other countries. It turned out that Jameel and their loyal Voice of Indonesia listeners had the opportunity to come to Indonesia because they won an international quiz held by Voice of Indonesia which is held once a year. That's one way Voice of Indonesia builds relationships with its loyal listeners and it's also one of Voice of Indonesia's ways of promoting Indonesia to foreign listeners. On this occasion also Voice of Indonesia showed clearly about the beauty of Indonesia to representatives of other citizens who won the quiz.

The main actor in diplomacy is the main characteristic of traditional diplomacy, where the main actor of diplomacy is the country represented by its representative in the destination country. Although the effects of globalization have presented new actors in relations between countries, the state is still the main player and coordinator in the implementation of public diplomacy. (Rahmawati, 2016). Non-state actors in diplomacy have become an inseparable part in situations where every individual and group is connected to one another. Non-state actors, referring to Hill's opinion, are individuals or groups, even though they use the facilities provided by the state, they do not need the government to carry out international relations. (Rahmawati, 2016). Actors involved in this program are from government and non-government circles. The selection of speakers in the program is in accordance with the themes discussed in the program. This is supported by a statement from the moderator, namely Daulat Pane. When the researcher asked about his response to the diplomatic program of the forum. he also answered an RRI foreign broadcast program that was broadcast in English involving diplomatic countries or high-ranking state officials to discuss issues that were currently being discussed.

\section{CONCLUSION}

In this chapter the researcher draws conclusions to answer the questions and objectives of the research conducted. The conclusions obtained from the results of the study are as follows, the role of Voice of Indonesia as a medium of public diplomacy in the Diplomatic Forum program is to become a bridge of information between the Indonesian government and the world. Diplomatic Forum aims to create a positive image of Indonesia to the world. The Diplomatic Forum program is one of the tangible forms of implementing the Vision and Mission of Voice of Indonesia to become one of Indonesia's broadcasters that builds the nation's character abroad and also creates a positive image of Indonesia abroad. Through this program, the foreign community will understand more about the policies that apply in Indonesia and promote Indonesia to the international arena with the results of discussions conducted by competent resource persons in their fields. The Diplomatic Forum program is a form of introducing the Voice of Indonesia to citizens of the world.

\section{REFERENCES}

Ardianto. E, Komala.L, Karlinah S. (2009). Komunikasi Massa Suatu Pengantar Edisi Revisi. Bandung: Refika Offset.

Alam. S, Nyarimun J. A. (2017). Jurnal Hubungan Internasional. Musik K-pop sebagai Alat Diplomasi dalam Soft Power Korea Selatan. Vol. 3 No. 1. Diperoleh dari http://isip.usni.ac.id/jurnal/5\%20Syafril\%20Alam\%20dan\%20Ansgra $\% 20$ Jenifer\%20Nyarimun.pdf 
Ardianti. N. (2015). Jurnal Ilmu Komunikasi. Peran Media Massa Nasional dalam Politik Internasional. Vol.45 No.1, diperoleh dari https://journal.uny.ac.id/index.php/informasi/article/viewFile/7769/6686

Arie. (2015, Agustus 17). Voice of Indonesia RRI Jakarta. diakses melalui https://radiomaya.blogspot.co.id/2015/08/voice-of-indonesia-rri-jakarta.html.

Alam, S (2016). Penggunaan Teknologi Informasi dalam Diplomasi Modern Departemen Luar Negeri RI. Jurnal Hubungan Internasional. Vol. 2 No. 1 Diperoleh dari http://isip.usni.ac.id/jurnal/9\%20Syafril\%20Alam.pdf.

Barston. (1988). Modern Diplomasi. New York: Longman Group UK Limited.

Barston. (2014). Modern Dilomacy. New York:Routledge.

Coffey, H. (Oktober 16, 2017). Most Dangerous Cities: From Jakarta to Karachi, these place score Lowest on New Index. Diakses melalui https://www.independent.co.uk/travel/news-and-advice/most- dangerous cities-quito-manila-jakarta-karachi-economist-index-2017- a8002476.html

Denzin, K. N \& Lincoln, S. Y. (2009). Handbook of Qualitative Research. Yogyakarta:Pustaka Pelajar

Fakhruddin, M. (Juli, 27 2017). Begini Persepsi Indonesia di Mata Media Internasional. Diakses melalui https://www.republika.co.id/berita/nasional/umum/17/07/27/otr0kf327 -begini-persepsi-indonesia-di-mata-media-internasional.

Feriany, V. (2009). Memperkuat Diplomasi Pencitraan Indonesia. Volume 1. No.1. Diperoleh dari buku Jurnal Diplomasi berjudul Demokrasi dan Diplomasi RI. Jakarta: Pusat Pendidikan dan Pelatihan Departemen Luar Negeri berdasarkan SK Kapusdiklat nomor: SK.12A/OT/II/2009/22.

Iqbal, M. (September 27, 2016). Jokowi Ingin Indonesia Punya Citra Yang Jelas di Mata Dunia. Diakses melalui https://news.detik.com/berita/d -3307964/jokowi ingin-indonesia-punya-citra-yang-jelas-di-mata-dunia

Ma'mun, S, A. (2012). Jurnal ilmu komunikologi. Diplomasi publik dalammembangun citra negara. Vol. 9 No.2. diperoleh dari https://www.esaunggul.ac.id/diplomasipublik-dalam-membangun citra-negara/

Morrisan, Wardhani, C.A , Hamid, F. (2013). Teori Komunikasi Massa. Bogor: Penerbit Ghalia Indonesia.

Moleong, L.J. (2016). Metode Penelitian Kualitatif. Bandung: PT. Remaja Rosdakarya.

Muhammad, H. (Desember 17, 2017). Wartawan dan Media Berperan Bangun Diplomasi. Diakses melalui http://nasional.republika.co.id/berita/nasional/umum/17/12/17/p13yz4380- wartawandan-media-berperan-bangun-diplomasi

Nurudin (2007). Penghantar Komunikasi Massa. Jakarta: PT. RajagrafindoPersada

Morissan. (2008). Manajemen Media Penyiaran: Strategi Mengelola Radio \& Televisi. Jakarta: Kencana Prenada Media Group 
Leonard, M (2002). Public Diplomacy. Diakses melalui www.fpc.org.uk

Permadi, D. (2009). Media Massa Sebagai Instrumen Diplomasi Amerika Serikat Dalam Kasus Invasi ke Irak dan Afganistan. Vol. 3 No. 2. Diperolah dari http://scriptura.petra.ac.id/index.php/iko/article/view/18317

Rachmawati, I. (2016). Diplomasi Publik; Meretas Jalan Bagi Harmoni dalam Hubungan Antarnegara. Yogyakarta: Calpulis.

Rusadi, U. (2015). Kajian Media: Isu Ideologis Dalam Perspektif, Teori Dan Metode. Jakarta: PT. RajaGrafindo Persada.

Roy. (1991). Diplomasi. Jakarta: Rajawali Pers.

Rivers, L. W, Jensen, W. L, Peterson, T. (2005). Media Massa \& Masyarakat Modern. Jakarta: Prenadamedia Group

Sanjaya, R (April, 8 2011). Meningkatnya Peran Media Dalam Diplomasi Indonesia.

Diakses melalui https://id.scribd.com/document/55875774/Meningkatnya Peran-Media -Dalam-Diplomasi-Indonesia

Setiyaji, A, Patria, B, Partho, G. (2015). Radio The Untold Stories. Bandung: $\quad$ Simbiosa Rekatama Media

Situs Resmi Radio Republik Indonesia. Diakses melalui http://rri.co.id/voi/berita/sejarah_voice_of_indonesia.html

Situs Resmi Radio Republic Indonesia. Diakses melalui http://rri.co.id/voi/berita/diplomatic_forum.html

Sugiyono. (2009). Metode Penelitian Kuantitatif Kualitatif dan R\&D.Bandung: CV. Alfabeta.

Sugiyono. (2016). Metodologi Penelitian Kombinasi. Bandung: Alfabeta.

Sugiyono. (2017). Metode Penelitian Kualitatif. Bandung: Alfabeta.

Sumateranews. (Agustus, 25 2018). Mahasiswa FKIP Ikuti Forum Diplomatik. Diakses melalui http://sumateranews.co.id/?p=24372

Suryokusomo, S. (2004). Praktik Diplomasi. Jakarta: CV. Amabel Mulia Asa.

Triyono, A. (2018). Peliputan Media Online atas Kebijakan Politik RI terhadap Krisis Qatar untuk Mendukung Diplomasi Internasional Vol. 1 No.2. Diperoleh dari https://jurnal.unpand.ac.id/index.php/egr/article/view/902

Tamara, W, R. (2017). Ejournal hubungan Ilmu Hubungan Internasional. Vol 5 No 3. Potensi Film Sebagai Sarana Diplomasi Publik Indonesia (Partisipasi Indonesia dalam Berlinale International Film Festival). Diperoleh dari http://ejournal.hi.fisipunmul.ac.id/site/wp content/uploads/2017/08/JURNAL\%20RIPTANTI\%20WIDYA\%20TAMARA\%20(0 8-29-17-03-16-13).pdf

Tamburaka, A. (2012). Agenda Setting Media Massa. Jakarta: PT. Rajagrafindo Persada Tohirin. (2012). Metode Penelitian Kualitatif Dalam Pendidikan dan Bimbingan Konseling. Jakarta: Rajawali Pers.

Widhasati, B. G, Damayanti, C, Sardjono S. H. (2017).Jurnal Ilmu Sosial. Diplomasi 
Publik Pemerintah Republik Indonesia melalui Pariwisata Halal. Vol. 1 No. 1 Diperoleh dari http://ejurnal.unisri.ac.id/index.php/sldrts/article/view/1956

Voice of Indonesia. (2017). Deksripsi acara Diplomatic Forum. Jakarta:Dokumentasi Pribadi Milik Voice of Indonesia.

Voice of Indonesia. (2017). Rekap Diplomatic Forum tahun 2017. Jakarta: Dokumentasi Pribadi Milik Voice of Indonesia.

Voice of Indonesia. Gambaran Umum Organisasi dan Susunan Struktur Organisasi. Jakarta: Dokumentasi Pribadi Milik Voice of Indonesia.

Voice of Indonesia. (2017). Streaming dan Deskripsi Siaran tahun 2018. Jakarta: Dokumentasi Pribadi Milik Voice of Indonesia. 